\title{
Development of feeding systems and strategies of supplementation to enhance rumen fermentation and ruminant production in the tropics
}

\author{
Metha Wanapat ${ }^{1 *}$, Sungchhang Kang ${ }^{1}$ and Sineenart Polyorach ${ }^{2}$
}

\begin{abstract}
The availability of local feed resources in various seasons can contribute as essential sources of carbohydrate and protein which significantly impact rumen fermentation and the subsequent productivity of the ruminant. Recent developments, based on enriching protein in cassava chips, have yielded yeast fermented cassava chip protein (YEFECAP) providing up to $47.5 \%$ crude protein (CP), which can be used to replace soybean meal. The use of fodder trees has been developed through the process of pelleting; Leucaena leucocephala leaf pellets (LLP), mulberry leaf pellets (MUP) and mangosteen peel and/or garlic pellets, can be used as good sources of protein to supplement ruminant feeding. Apart from producing volatile fatty acids and microbial proteins, greenhouse gases such as methane are also produced in the rumen. Several methods have been used to reduce rumen methane. However, among many approaches, nutritional manipulation using feed formulation and feeding management, especially the use of plant extracts or plants containing secondary compounds (condensed tannins and saponins) and plant oils, has been reported. This approach could help todecrease rumen protozoa and methanogens and thus mitigate the production of methane. At present, more research concerning this burning issue - the role of livestock in global warming - warrants undertaking further research with regard to economic viability and practical feasibility.
\end{abstract}

Keywords: Feed resources, Feeding system, Methane, Plant secondary compounds, Ruminants

\section{Introduction}

Animals have been an important component in integrated crop-livestock farming systems in developing countries. In a diversified role, they produce animal protein food, draft power and farm manure as well as ensuring social status and enriching people's livelihoods [1]. As the world population is expected to increase from 6 billion to about 8.3 billion in the year 2030 at an average growth rate of $1.1 \%$ per $\mathrm{yr}$, it is essential to be prepared to produce sufficient food for the increased population based on locally available resources especially in the developing countries. The consumption of animal food was $10 \mathrm{~kg} / \mathrm{yr}$ in the $1960 \mathrm{~s}$ increasing to $26 \mathrm{~kg} / \mathrm{yr}$ in 2000 and is expected to be $37 \mathrm{~kg} / \mathrm{yr}$ by 2030 [2,3]. Livestock production, in particularly buffalo, cattle and small ruminants, is

\footnotetext{
* Correspondence: metha@kku.ac.th

'Tropical Feed Resources Research and Development Center (TROFREC), Department of Animal Science, Faculty of Agriculture, Khon Kaen University, Khon Kaen 40002, Thailand

Full list of author information is available at the end of the article
}

an integral part of food production systems, making important contributions to the quality and diversity of the human food supply as well as providing other valuable services such as work and nutrient recycling. Large increases in per capita and total demand for meat, milk and eggs are forecast for most developing countries for the next few decades [4]. In developed countries, per capita intakes are forecast to change slightly, but the increases in developing countries, with their larger populations and more rapid population growth rates, will generate a very large increase in global demand. Most importantly, the conversion of materials inedible for humans, such as roughage, tree fodder, crop residues and by-products, into human food by ruminant animals will continue to serve as an important function of animal agriculture. However, since much of the projected increase is expected to come from pork, poultry and aquaculture production, and especially from species consuming diets high in forage carbohydrate, meeting future demand will depend substantially on achievable increases in cereal yields. Therefore, there 
are opportunities and challenges for researchers to increase animal productivity through the application of appropriate technologies, particularly in production systems, nutrition and feeding. Wanapat [5] and Devendra and Leng [6] have emphasized the utmost importance of using local feed resources as the key driving force to increase the productivity of animals in Asia.

Global warming is a highly important issue which affects the environment and livestock production. Total emissions of greenhouse gases (GHG) from agriculture, including livestock, are estimated to be between $25 \%$ and $32 \%$, depending on the source $[7,8]$ and on the proportion of land conversion that is ascribed to livestock activities. Interestingly, Goodland and Anhang [9] reported that livestock production and its by-products are responsible for at least 51 percent of global warming gases, accounting for at least 32.6 billion tons of carbon dioxide per yr. Carbon dioxide provides most GHG (55-60\%) followed by methane (15$20 \%)$. Therefore, livestock is one source of methane production through fermentation in the rumen. Gas emissions from the livestock sector are estimated at between 4.1 and 7.1 billion tons of $\mathrm{CO}_{2}$ equivalents per yr, equating to 15-24 $\%$ of total global anthropogenic GHG emissions [10].

Tropical plants normally contain a high to medium content of secondary compounds such assaponins and condensed tannins, which have been shown to exert a specific effect against rumen protozoa while leaving the rest of the rumen biomass unaltered [11]. Numerous studies have determined the effects of feeding ruminants with saponin-rich plants such as Enterelobium cyclocarpum, Spinadus saponaria, Sapindus rarak, Sesbania sesban, Quillajasaponaria, Acaciaauriculoformis and Yucca schidi gera $[11,12]$. Results have indicated that saponins have a strong anti-protozoal activity and could thus serve as an effective defaunating agent for ruminants due to their detergent action [13]. Numerous studies [14-16] have recently reported the impact of livestock on global warming and suggested approaches to mitigate rumen methane.

\section{Development of pelleted feeds}

Pelleted feeds have been used successfully for fish and animals including non-ruminant and ruminant animals, fish and shrimp. The advantages of pelleted feeds include: (1) preventing selective feeding on those ingredients in the formulation which are more palatable and thus more desirable to the animal; (2) preventing the separation of constituents in animal feeds due to varying size and density; (3) providing higher bulk density, which has advantages both for shipping and handling, resulting in maximum load efficiency and reduced storage requirements; and (4) improving nutrient utilization and so increasing the feed conversion rate. Pelleting also improves the acceptability, density and keeping quality of feedstuffs [17]. Generally, pelleted feeds are produced in an extrusion- type thermoplastic melding operation in which finely divided particles of a feed ration are formed into compact, easily-handled pellets. Binder additives may be used to improve the strength and shelf-life of pellets and to reduce the release of fines during the pelleting process. Preferably, nutritive binder additives are used which also provide essential recognized nutrients such as magnesium, calcium, potassium and/or sulfur to the feed.

Recently, scientists have been interested in pelleting local feed resources and agricultural cropresidues, such as mangosteen (Garcinia mangostana) peel, mulberry (Morus alba), Leucaena (Leucaena leucocephala), sweet potato (Ipomoea batatas) vine, to improve the nutritive value and its utilization. Pellet products such as Mago-pel (mangosteen peel pellet), Maga-lic (mangosteen peel with garlic powder pellet), Maga-ulic (mangosteen peel pellet with urea and garlic powder), LLP (leucaena leaf pellet), MUP (mulberry leaf pellets) and SWEPP (sweet potato vine pellet with $10 \%$ urea) have been prepared following the steps shown in Table 1 and Figure 1.

Huyen et al. [18] and Tan et al. [19] have reported that supplementation with mulberry leaf pellets (MUP) improved nutrient digestibility and rumen fermentation. MUP could be used as a protein source to improve rumen efficiency and production especially supplementation at $600 \mathrm{~g} / \mathrm{d}$ for beef cattle when fed on low-quality roughage such as rice straw. Norrapoke et al. [20] showed that the combined use of concentrates containing 16\% CP with Mago-pel at $300 \mathrm{~g} / \mathrm{hd} / \mathrm{d}$ resulted in changes in rumen fermentation and microbial population and an improvement in milk production in lactating dairy crossbreds. Manasri et al. [21] reported that supplementation with Maga-lic at $200 \mathrm{~g} / \mathrm{hd} / \mathrm{d}$ improved ruminal fermentation, especially increasing the proportion of propionate and reducing methane gas production in beef cattle steers. Furthermore, Trinh et al. [22] compared non-supplemented and pelletsupplemented groups of beef cattle (Mago-pel, Maga-lic and Mago-ulic at $200 \mathrm{~g} / \mathrm{hd} / \mathrm{d}$ ) It was found that total dry matter intake (DMI) and digestibility of DM and CP were not significantly affected by pellet supplementation when compared with the control group $(P>0.05)$. In addition, the acetate content, the acetate:propionate ratio, the protozoa population and methane production were all reduced, whereas the propionate production and bacterial population increased in the pellet-supplemented group and were highest in the Maga-ulic-supplemented treatment. The Maga-ulic supplemented treatment also provided the highest level of microbial protein synthesis when compared with the other treatments. Hung et al. [23] reported that LLP supplementation significantly increased rice straw intake and total intake. There was also an increase in the population of fungal zoospores, amylolytic bacteria, proteolytic bacteria and cellulolytic bacteria with an increasing level of LLP supplementation while the 
Table 1 Feed ingredients and chemical composition of Mago-pel, Maga-lic, Maga-ulic, LLP, MUP and SWEPP

\begin{tabular}{|c|c|c|c|c|c|c|}
\hline Items & Mago-pel & Maga-lic & Maga-ulic & LLP & MUP & SWEPP \\
\hline Ingredients & \multicolumn{6}{|c|}{$\%$ of dry matter } \\
\hline Mangosteen peel powder & 98.5 & 93.5 & 91.5 & - & - & - \\
\hline Garlic powder & - & 5 & 5 & - & - & - \\
\hline Leucaena leaf meal & - & - & - & 81 & - & - \\
\hline Mulberry meal & - & - & - & - & 82 & - \\
\hline Sweet potato vine & - & - & - & - & - & 81.5 \\
\hline Cassava starch & 0.5 & 0.5 & 0.5 & 0.5 & 0.5 & 0.5 \\
\hline Urea & - & - & 0.2 & 10 & 10 & 10 \\
\hline Molasses & 1 & 1 & 1 & 5 & 4.5 & 5 \\
\hline Sulfur & - & - & - & 1 & 1 & 1 \\
\hline Mineral mixture & - & - & - & 1 & 1 & 1 \\
\hline Salt & - & - & - & 1 & 1 & 1 \\
\hline \multicolumn{7}{|l|}{ Chemical composition } \\
\hline \multirow[t]{2}{*}{ Dry matter } & 93.3 & 93.1 & 92.7 & 92.9 & 92.3 & 95.6 \\
\hline & \multicolumn{6}{|c|}{$\%$ of dry matter } \\
\hline Organic matter & 96.5 & 96.4 & 96.5 & 91.3 & 88.2 & 81.4 \\
\hline Crude protein & 21.2 & 21.5 & 22.1 & 42.2 & 48.7 & 40.5 \\
\hline Neutral detergent fiber & 57.3 & 57.2 & 57 & 44 & 20.4 & 33.1 \\
\hline Acid detergent fiber & 48.6 & 48.2 & 48.3 & 20 & 14.5 & 27.8 \\
\hline
\end{tabular}

Abbreviations: Mago-pel mangosteen peel pellet, Maga-lic mangosteen peel with garlic powder pellet, Maga-ulic mangosteen peelpellet with urea and garlic powder, LLP leucaena leaf pellet, MUP mulberry leaf pellets, SWEPP sweet potato vine pellet with $10 \%$ urea.

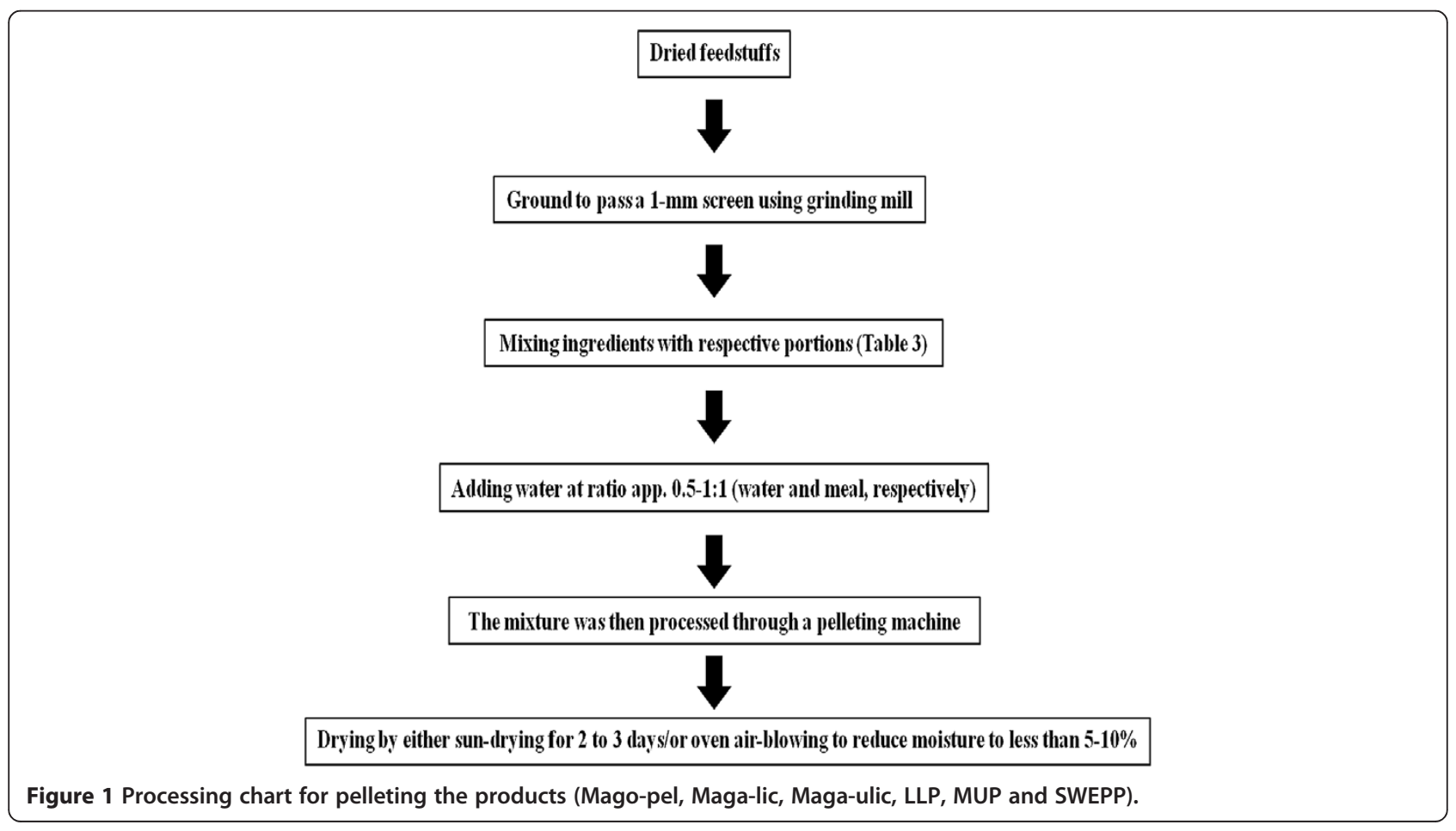


population of rumen protozoa decreased. The population of total bacteria and the three predominant cellulolytic bacteria increased when the level of LLP supplementation increased; meanwhile, the population of methanogenic bacteria decreased. Supplementation with LLP resulted in an improvement in nitrogen balance and microbial nitrogen supply. Recently, Phesatcha and Wanapat [24] revealed that SWEPP was a good source of protein supplement improving apparent digestibility, rumen fermentation, and milk yield in lactating dairy cows. A summary of the experimental data above is presented in Table 2.

\section{Yeast fermented cassava chip protein (YEFECAP)}

Cassava chip and other forms of cassava root can be successfully fermented with yeast (Saccharomyces cereviceae) to obtain a final product with high $\mathrm{CP}$ and a relatively high profile of amino acids [25,26]. The amino acid profile of YEFECAP is presented in Figure 2, showing a high level of lysine, glutamic acid, leucine and phenylalanine. Supplementation with YEFECAP to replace soybean meal in concentrates for lactating dairy cows resulted in a good performance in milk yield $(15.7 \mathrm{~kg} / \mathrm{d})$ [27].

Dietary yeast can be used as a ruminant feed especially Saccharomyces cerevisiae because the yeast cell contains useful nutrients for ruminant feed, especially a high lysine content $(7.6 \pm 0.7 \mathrm{~g} / 16 \mathrm{~g} \mathrm{~N})[26,28,29]$. Moreover, the addition of yeast to the ruminant diet can not only improve the rumen environment but also enhance microbial activities (especially cellulolytic activities so that they increase fiber digestion, reduce lactate accumulation and the concentration of oxygen in rumen fluid and improve the utilization of starch [30,31]. In addition, S. cerevisiae could also stimulate DM intake and productivity in growing and lactating cattle [32] and improve microbial protein synthesis and milk production in dairy cows [33,34]. However, Desnoyers et al. [35] reported that the highly variable effects of live $S$. cerevisiae cultures could be associated with the ratio of forage to concentrate used. Cassava chip is an energy source with low crude protein, but when fermented with yeast can increase crude protein from 1-3\% CP to $30.4 \%$ CP [36]. Recently, Polyorach et al. [26,29] reported that YEFECAP could be prepared with aCP level up to $47 \%$. The YEFECAP was prepared according to the method of Polyorach et al. [29] as shown in Table 3 and Figure 3.

The beneficial use of YEFECAP has been evaluated by Boonnop et al. [37] and Wanapat et al. [27,38]. Boonnop et al. [37] studied the effects of replacing soybean meal with YEFECAP on rumen ecology and nutrient digestibility in dairy crossbred steers. It was found that YEFECAP could replace soybean meal completely and was beneficial to cattle in terms of the efficiency of rumen fermentation, microbial protein synthesis, nitrogen retention and nutrient digestibility. Khampa et al. [39] reported that supplementation with YEFECAP could replace $75 \%$ of concentrate to improve ruminal fermentation efficiency and average daily gain and also reduce the cost of production in dairy heifers. Supplementation with YEFECAP could improve the population of bacteria and fungal zoospores, but decrease the population of Holotrich and Entodiniomorph protozoain the rumen of dairy steers [40]. Polyorach et al. [41] and Wanapat et al. $[27,38]$ revealed that using YEFECAP to replace soybean meal at 0, 33, 67 and 100\% CP could enhance milk yield, milk fat and milk protein with increasing YEFECAP level and was highest at a $100 \%$ level of replacement. Moreover, Wanapat et al. [38] compared four sources of protein in concentrate diets, soybean meal (SBM), cassava hay $(\mathrm{CH})$, Leucaena leucocephala (LL) and YEFECAP in lactating dairy cows and found that $\mathrm{CP}$ digestibility was highest in $\mathrm{CH}$ - and YEFECAP-supplemented groups. Propionic acid content was highest in cows receiving $\mathrm{CH}$ and YEFECAP, while populations of ruminal fungi, proteolytic and cellulolytic bacteria were highest with YEFECAP supplementation. Milk fat and milk protein content significantly increased in cows fed with $\mathrm{CH}$ and

Table 2 Effect of of Mago-pel, Maga-lic, Maga-ulic, LLP, MUP, SWEPP on DMI, digestibility, rumen volatile fatty acid (VFA) production and ruminal microorganisms

\begin{tabular}{|c|c|c|c|c|c|c|c|c|c|c|c|}
\hline \multirow[t]{2}{*}{ Pelleting } & \multirow[t]{2}{*}{ Suppl. } & \multirow[t]{2}{*}{ Animal } & \multirow[t]{2}{*}{ DMI } & \multirow[t]{2}{*}{ Dig. } & \multicolumn{3}{|c|}{ VFA } & \multirow[t]{2}{*}{$\mathrm{CH}_{4}$} & \multirow[t]{2}{*}{ MPS } & \multirow[t]{2}{*}{ Prot. } & \multirow[t]{2}{*}{ Reference } \\
\hline & & & & & $\mathrm{C} 2$ & C3 & C4 & & & & \\
\hline MUP & $600 \mathrm{~g} / \mathrm{hd} / \mathrm{d}$ & Buffalo & $\uparrow$ & $\uparrow$ & $\downarrow$ & $\uparrow$ & $\uparrow$ & $\downarrow$ & nd & $\downarrow$ & [18] \\
\hline MUP & $600 \mathrm{~g} / \mathrm{hd} / \mathrm{d}$ & Buffalo & $\uparrow$ & nd & nd & nd & nd & nd & $\uparrow$ & nd & [19] \\
\hline Mago-pel & $300 \mathrm{~g} / \mathrm{hd} / \mathrm{d}$ & Dairy cow & nc & $\mathrm{nc}$ & $\mathrm{nc}$ & $\mathrm{nc}$ & $\mathrm{nc}$ & $\mathrm{nc}$ & $\uparrow$ & $\downarrow$ & [20] \\
\hline Maga-lic & $200 \mathrm{~g} / \mathrm{hd} / \mathrm{d}$ & Dairy steer & $\mathrm{nc}$ & $\uparrow$ & $\downarrow$ & $\uparrow$ & $\mathrm{nc}$ & $\downarrow$ & nd & $\downarrow$ & [21] \\
\hline Maga-ulic & $200 \mathrm{~g} / \mathrm{hd} / \mathrm{d}$ & Dairy steer & nc & $\uparrow$ & $\downarrow$ & $\uparrow$ & nc & $\downarrow$ & $\uparrow$ & $\downarrow$ & [22] \\
\hline LLP & $450 \mathrm{~g} / \mathrm{hd} / \mathrm{d}$ & Buffalo & $\uparrow$ & nd & nd & nd & nd & nd & $\uparrow$ & $\downarrow$ & [23] \\
\hline
\end{tabular}

Abbreviations: MUP mulberry leaf pellet, Mago-pel mangosteen peel pellet, Maga-lic mangosteen peel and garlic pellet, Maga-ulic mangosteen peel, garlic and urea pellet, LLP leucaena leaf pellet, VFA volatile fatty acid, C2 acetic acid, C3 propionic acid, C4 butyric acid, $\mathrm{CH}_{4}$ methane production, increase ( $\left.\uparrow\right)$, decrease $(\downarrow)$ from control group, nd not determined, nc no change. 


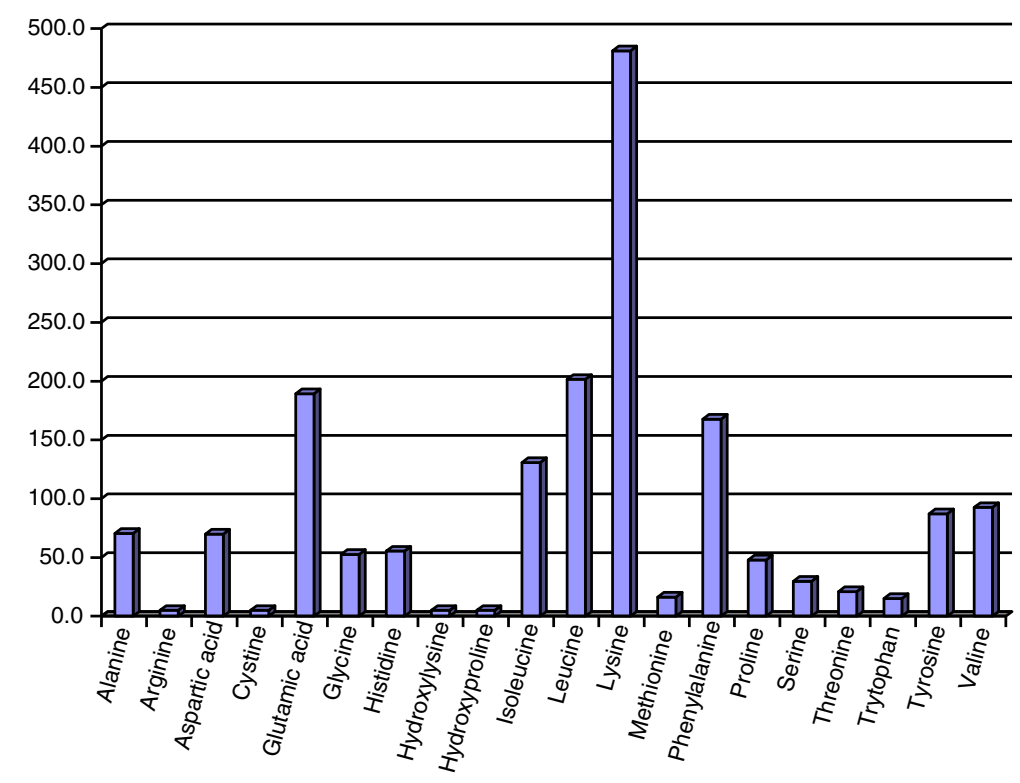

Figure 2 Amino acid profile of YEFECAP products (mg/100 $\mathrm{g}$ of YEFECAP). Source: Polyorach et al. [26].

YEFECAP $(P<0.05)$. Based on these studies, YEFECAP can be practically prepared and used as an alternative protein source in ruminant feeding (Table 4).

Wanapat et al. [27,38] reported on a study using YEFECAP to replace soybean meal (SBM) in concentrate mixtures for early lactating cows. It was found that YEFECAP can completely replace SBM in concentrate mixtures for milking dairy cows while enhancing rumen fermentation, dry matter intake, nutrient digestibility, milk yield and composition. A summary of the above research data is shown in Table 5.

Use of plant secondary compounds in methane reduction Plant secondary compounds (condensed tannins and saponins) are important ruminant feed additives, particularly for a methane mitigation strategy because of their natural origin as opposed to chemical additives (Figure 4).

Table 3 Chemical composition of yeast fermented cassava chip protein (YEFECAP)

\begin{tabular}{lc}
\hline Chemical composition & YEFECAP \\
\hline Dry matter & \% of dry matter \\
Organic matter & 97.2 \\
Crude protein & 47.5 \\
Ether extract & 7.9 \\
Neutral detergent fiber & 6.1 \\
Acid detergent fiber & 4.3 \\
\hline
\end{tabular}

Source: Polyorach et al. [26].
Anti-methanogenic activity can be attributed to both condensed tannins and hydrolysable tannins. There are two modes of action of tannins in methanogenesis: a direct effect on ruminal methanogens and an indirect effect on hydrogen production due to lower feed degradation. There is also evidence that some condensed tannins (CT) can reduce methane emissions while reducing bloat and increasing amino acid absorption in the small intestine. Methane emissions are also commonly lower with higher proportions of forage legumes in the diet, partly due to lower fiber contact, a faster rate of passage and, in some cases, the presence of condensed tannins $[42,43]$. Supplementation with Phaseolus calcaratus hay $(\mathrm{PCH})$ at $600 \mathrm{~g} / \mathrm{hd} / \mathrm{d}$ was beneficial for swamp buffaloes fed rice straw as a basal roughage, as it resulted in increased DM intake, reduced protozoal numbers and methane gas production in the rumen, increased $\mathrm{N}$ retention as well as improving the efficiency of rumen microbial CP synthesis [44]. Legumes containing condensed tannin (e.g. Lotuses) are able to lower methane (based on $\mathrm{g} / \mathrm{kg} \mathrm{DMI}$ ) by $12-15 \%[42,45]$. Also, some authors have reported that condensed tannins can reduce methane production by 13 to $16 \%$ (DMI basis) $[46,47]$, mainly through a direct toxic effect on methanogens. More recently, Woodward et al. [47] carried out a similar trial with cows fed Lotus corniculatus and found that methane production were reduced,McAllister and Newbold [48] reported that extracts from plants such as rhubarb and garlic could also decrease methane emissions. However, there is little information on the effect of different saponins on rumen bacteria. In one study, Sirohi et al. [49] showed that plant secondary metabolites (PSM) at 


\section{Weigh $20 \mathrm{~g}$ of yeast into a flask and add $20 \mathrm{~g}$ sugar and $100 \mathrm{ml}$ distilled water, mixed well and incubate at room temperature for $1 \mathrm{~h}(\mathrm{~A})$}

Prepare medium, weigh and mix well with $8 \mathrm{~g}$ molasses, $100 \mathrm{ml}$ distilled water, $64 \mathrm{~g}$ urea and then aljust $\mathrm{pH}$ of medium solution using $\mathrm{H}_{2} \mathrm{SO}_{4}$ to achieve final $\mathrm{pH} 3.5-5$ (B)
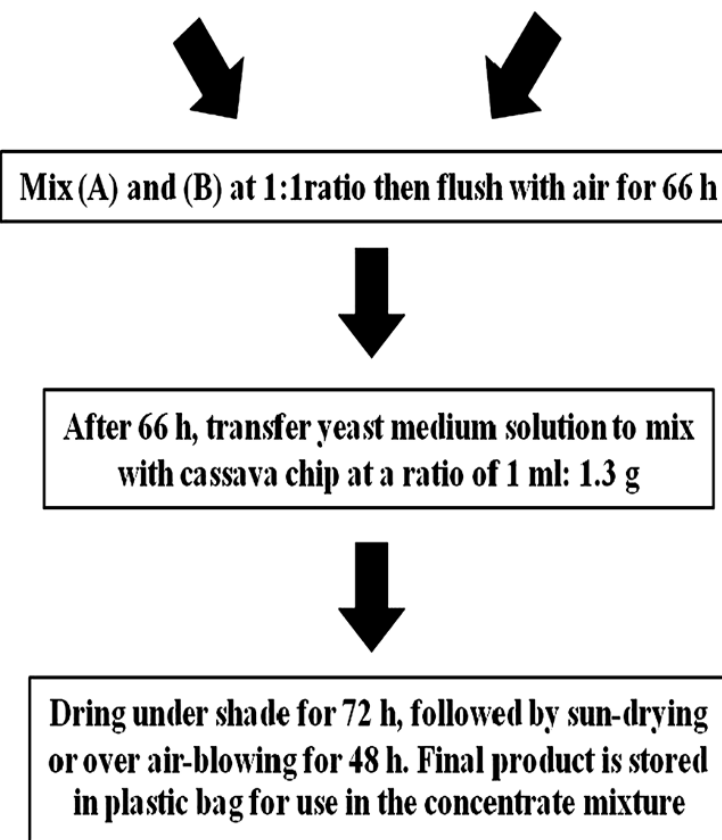

Figure 3 Process chart for yeast fermented cassava chip products (YEFECAP) preparation. Polyorach et al. [29].

low concentrations could be used to manipulate rumen fermentation favorably. At an appropriate dose, saponins or saponin-containing plants have been shown to suppress the protozoal population, increase the bacteria and fungi population, the production of propionate, the partitioning factor, the yield and efficiency of microbial protein synthesis and to decrease methanogenesis, all of which improve performance in ruminants. Tannins, especially condensed tannins (CT), also decrease methane production and increase the efficiency of microbial protein synthesis. Plant extracts, rich in flavonoids, increase the degradation of cell wall constituents and also the yield and efficiency of microbial protein synthesis [49].
Saponins are natural detergents found in many plants. Interest has increased in using saponin-containing plants as a possible means of suppressing or eliminating protozoa in the rumen. Decreased numbers of ruminal ciliate protozoa may enhance the flow of microbial protein from the rumen, to increase the efficiency of feed utilization and decrease methanogenesis. Saponins are also known to influence both the composition and number of ruminal bacterial species through specific inhibition or selective enhancement of the growth of individual species. Saponins have been shown to possess strong defaunation properties both in vitro and in vivo which could reduce methane emissions [45]. Beauchemin et al. [42] recently reviewed

Table 4 Effect of using YEFECAP as a protein source in ruminants on DMI, digestibility, rumen volatile fatty acid (VFA) production, ruminal microorganisms, and milk production in various studies

\begin{tabular}{|c|c|c|c|c|c|c|c|c|c|c|c|c|c|c|}
\hline \multirow[t]{2}{*}{ Animal } & \multirow[t]{2}{*}{ DMI } & \multirow[t]{2}{*}{ Dig. } & \multirow[t]{2}{*}{ TVFA } & \multirow[t]{2}{*}{$\mathrm{C2}$} & \multirow[t]{2}{*}{$\mathrm{C} 3$} & \multirow[t]{2}{*}{$\mathrm{C} 2: \mathrm{C3}$} & \multirow[t]{2}{*}{ Bact } & \multirow[t]{2}{*}{ Prot } & \multirow[t]{2}{*}{ Fung } & \multirow[t]{2}{*}{ MSP } & \multicolumn{3}{|c|}{ Milk } & \multirow[t]{2}{*}{ Reference } \\
\hline & & & & & & & & & & & Yield & Fat & Protein & \\
\hline Lactating dairy cows & $\uparrow$ & $\uparrow$ & $\uparrow$ & nc & $\uparrow$ & $\downarrow$ & $\uparrow$ & nc & $\uparrow$ & nd & $\uparrow$ & $\uparrow$ & $\uparrow$ & {$[27]$} \\
\hline Dairy steers & $\uparrow$ & $\uparrow$ & $\uparrow$ & $\downarrow$ & $\uparrow$ & $\downarrow$ & $\uparrow$ & $\downarrow$ & $\uparrow$ & $\uparrow$ & nd & nd & nd & {$[37]$} \\
\hline Lactating dairy cows & ns & $\uparrow$ & $\uparrow$ & $\mathrm{nc}$ & $\uparrow$ & nd & $\uparrow$ & $\downarrow$ & $\uparrow$ & nd & $\mathrm{nc}$ & $\uparrow$ & $\uparrow$ & [38] \\
\hline
\end{tabular}


Table 5 Effect of YEFECAP as a protein source in concentrate mixtures on milk production, milk composition and economic return

\begin{tabular}{|c|c|c|c|c|c|c|c|c|}
\hline \multirow[t]{2}{*}{ Items } & \multicolumn{4}{|c|}{ Treatments } & \multirow[t]{2}{*}{ SEM } & \multicolumn{3}{|c|}{ Contrasts } \\
\hline & $\mathrm{T} 1$ & $\mathrm{~T} 2$ & T3 & $\mathrm{T} 4$ & & $\mathrm{~L}$ & $\mathbf{Q}$ & $\mathrm{C}$ \\
\hline \multicolumn{9}{|l|}{ Production } \\
\hline Milk yield, kg/d & 13.5 & 14.0 & 14.5 & 15.0 & 0.27 & $* *$ & ns & ns \\
\hline $3.5 \% \mathrm{FCM}^{1}, \mathrm{~kg} / \mathrm{d}$ & 13.7 & 14.7 & 15.9 & 17.1 & 0.49 & $* *$ & ns & ns \\
\hline \multicolumn{9}{|l|}{ Milk composition, \% } \\
\hline Protein & 4.0 & 4.1 & 4.5 & 4.7 & 0.17 & $* *$ & ns & ns \\
\hline Fat & 3.2 & 3.3 & 3.4 & 3.5 & 0.06 & $* *$ & ns & ns \\
\hline Lactose & 4.5 & 4.6 & 4.6 & 4.7 & 0.07 & ns & ns & ns \\
\hline Solids-not-fat & 8.2 & 8.4 & 8.4 & 8.5 & 0.29 & ns & ns & ns \\
\hline Total solids & 12.3 & 12.7 & 12.8 & 13.0 & 0.78 & ns & ns & ns \\
\hline Milk urea $\mathrm{N}, \mathrm{mg} / \mathrm{dL}$ & 14.8 & 12.5 & 12.3 & 12.0 & 0.58 & * & ns & ns \\
\hline \multicolumn{9}{|c|}{ Economic return, \$US/hd/d } \\
\hline Feed cost & 2.5 & 2.6 & 2.6 & 2.7 & 0.14 & ns & ns & ns \\
\hline Milk sale & 9.5 & 9.8 & 10.2 & 10.5 & 0.19 & $* *$ & ns & ns \\
\hline Profit & 7.0 & 7.2 & 7.6 & 7.8 & 0.16 & $* *$ & ns & ns \\
\hline
\end{tabular}

Source: Wanapat et al. [27].

ns, non-significance.

Level of replacement of soybean meal (SBM) by YEFECAP: at 0\% (T1), 33\% (T2), $67 \%$ (T3), 100\% (T4)

Feed cost: concentrate $T 1,0.38$ \$US $/ \mathrm{kg}, T 2,0.37 \$ \mathrm{US} / \mathrm{kg}, T 3,0.37$ WS $/ \mathrm{kg}, T 4$ $0.35 \$ \mathrm{US} / \mathrm{kg}$, ULRS, $0.07 \$ \mathrm{US} / \mathrm{kg}$, Milk price, $0.7 \$ \mathrm{US} / \mathrm{kg}$.

$L$, linear, $Q$, quadratic, $C$, cubic, $S E M$, standard error of the means; * $P<0.05$; ${ }^{* *} P<0.01$. the literature related to the effect of saponins on methane and concluded that although there is evidence for a reduction in methane from some sources of saponins, not all are effective [45]. While extracts of CT and saponins may be commercially available, their cost is currently prohibitive for their routine use in ruminant production systems. However, research is still required on the optimum sources of CT and saponins, the level of CT astringency (chemical composition) and the feeding methods and dose rates required to reduce methane and stimulate animal production.

Table 6 presents the data from both in vitro and in vivo trials using mangosteen peel powder (MP) with or without other sources on rumen fermentation. Based on these results, MP supplementation both for in vitro and in vivo trials significantly increased the production of total volatile fatty acids $(P<0.05)$, as well as propionate production, while acetate, butyrate production and the acetate:propionate ratio were significantly decreased $(P<0.05)$. Condensed tannins and saponins contained in MP could contribute to the above effects. Similar effects, especially regarding the acetate:propionate ratio, were found by Beauchemin and McGinn [50] while total volatile fatty acids were decreased. The effects of supplementation with MP on DM intake, digestibility and rumen methane production are reported in Table 7. These findings showed that MP supplementation did not affect DM intakes, while digestibility and rumen methane production (by estimation using volatile fatty acid concentration) were significantly decreased $(P<$ $0.05)$. The effects of MP supplementation on the population of ruminal microorganisms are shown in Table 8. MP

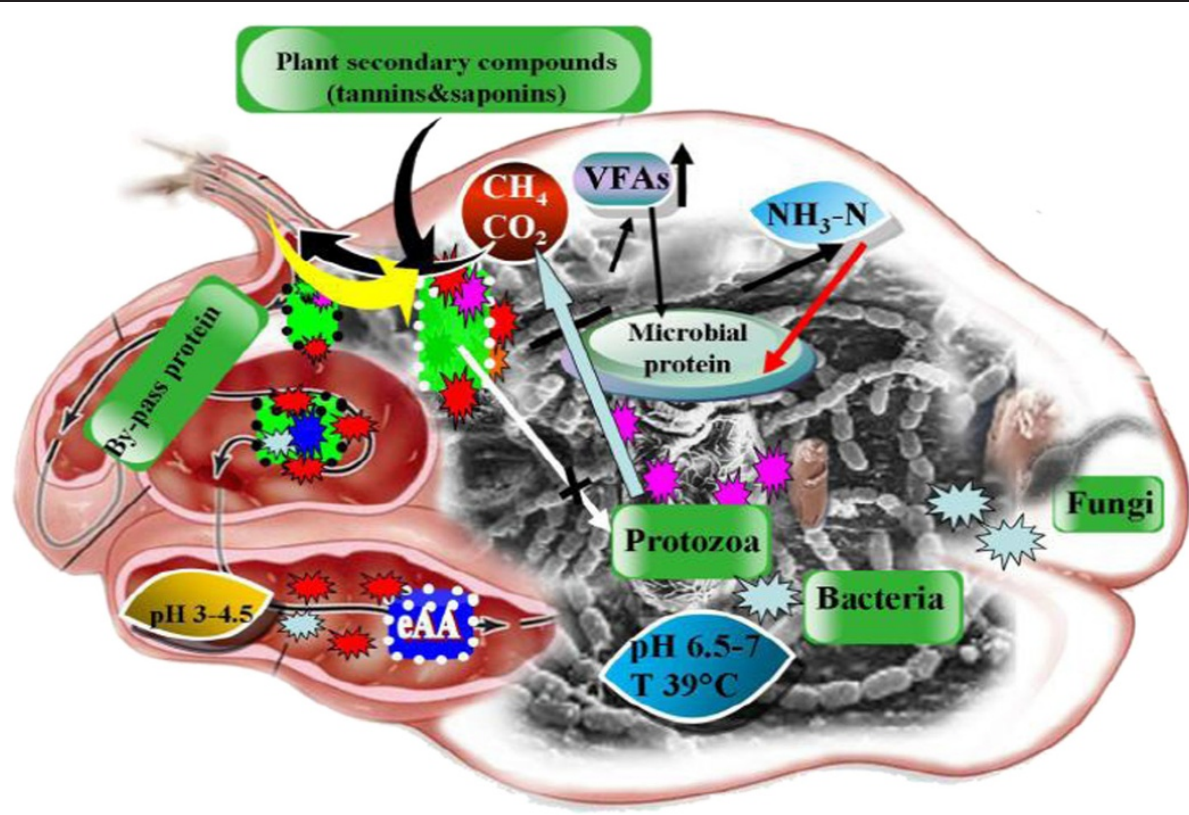

Figure 4 Role of plant secondary compounds (condensed tannins and saponins) on rumen fermentation process [1]. 
Table 6 Effect of mangosteen peel supplementation on rumen volatile fatty acid production in ruminants using in vitro and in vivo studies

\begin{tabular}{|c|c|c|c|c|c|c|c|c|}
\hline Substrate & Level & Species & TVFA & $C_{2}$ & $C_{3}$ & $\mathrm{C}_{4}$ & $\mathrm{C}_{2} / \mathrm{C}_{3}$ & References \\
\hline \multicolumn{9}{|l|}{ In vitro } \\
\hline MP & 200 mg & Steer & + & + & + & - & - & {$[52]$} \\
\hline \multicolumn{9}{|l|}{ In vivo } \\
\hline MP & $100 \mathrm{~g} / \mathrm{hd} / \mathrm{d}$ & Beef cattle & + & - & - & - & - & {$[52]$} \\
\hline MP & $200 \mathrm{~g} / \mathrm{hd} / \mathrm{d}$ & Dairy cows & + & - & + & + & - & [53] \\
\hline $\mathrm{MP}$ & $100 \mathrm{~g} / \mathrm{hd} / \mathrm{d}$ & Native cattle & + & - & + & - & - & [51] \\
\hline MP & $30 \mathrm{~g} / \mathrm{kg}$ & Buffalo & + & - & + & - & - & [54] \\
\hline MPP & $200 \mathrm{~g} / \mathrm{hd} / \mathrm{d}$ & Beef cattle & + & - & + & - & - & [22] \\
\hline MPP & $300 \mathrm{~g} / \mathrm{hd} / \mathrm{d}$ & Dairy cow & + & - & + & - & - & [20] \\
\hline \multicolumn{9}{|l|}{ Combination } \\
\hline $\mathrm{CO}+\mathrm{MP}$ & $50+30 \mathrm{~g} / \mathrm{kg}$ & Buffalo & - & - & + & - & - & {$[54]$} \\
\hline $\mathrm{MP}+\mathrm{GP}$ & $9+1 \%$ & Beef cattle & + & + & + & - & - & [22] \\
\hline $\mathrm{MP}+\mathrm{GP}$ pellet & $200 \mathrm{~g} / \mathrm{hd} / \mathrm{d}$ & Beef cattle & + & - & + & - & - & {$[22]$} \\
\hline
\end{tabular}

Abbreviations: GP garlic powder, MP mangosteen peel powder, MPP mangosteen peel pellet, $C O$ coconut oil, + increased, - decreased.

supplementation reduced rumen protozoa production remarkably, while the numbers of the predominant cellulolytic bacteria increased $(P<0.05)$. In addition, methanogen numbers tended to decrease. However, it was found that mangosteen peel powder significantly increased $(P<0.05)$ the cellulolytic bacteria population [51]. The condensed tannins and saponins present in the MP could influence such changes in the rumen.

There are five possible mechanisms by which lipid supplementation reduces methane: reducing fiber digestion (mainly in long chain fatty acids); lowering DMI (if total dietary fat exceeds 6-7\%); suppression of methanogens (mainly in medium chain fatty acids); suppression of rumen protozoa and to a limited extent through biohydrogenation
[42]. Oils offer a practical approach to reducing methane in situations where animals can be given daily feed supplements, but excess oil is detrimental to fiber digestion and animal production. Oils may act as hydrogen sinks but medium chain length oils appear to act directly on methanogens and reduce the numbers of ciliate protozoa. However, Kongmun et al. [55] reported that supplementation of coconut with garlic powder could improve in vitro ruminal fluid fermentation in terms of the volatile fatty acid profile, reduced methane losses and reduced protozoal population. Beauchemin et al. [42] recently reviewed the effects of the level of dietary lipid on methane emissions in 17 studies and reported that with beef cattle, dairy cows and lambs, there was a proportional reduction of 0.056

Table 7 Effect of mangosteen peel supplementation on intake, digestibility and methane production in ruminants using in vitro and in vivo studies

\begin{tabular}{|c|c|c|c|c|c|c|}
\hline Substrate & Level & Species & DMI & Dig & $\mathrm{CH} 4$ & References \\
\hline \multicolumn{7}{|l|}{ In vivo } \\
\hline MP & $100 \mathrm{~g} / \mathrm{hd} / \mathrm{d}$ & Beef cattle & + & + & - & {$[52]$} \\
\hline MP & $200 \mathrm{~g} / \mathrm{hd} / \mathrm{d}$ & Dairy cows & $\mathrm{nc}$ & + & - & [53] \\
\hline MP & $100 \mathrm{~g} / \mathrm{hd} / \mathrm{d}$ & Native cattle & $\mathrm{nc}$ & + & - & {$[55]$} \\
\hline MP & $30 \mathrm{~g} / \mathrm{kg}$ & Buffalo & nc & - & - & {$[54]$} \\
\hline MPP & $200 \mathrm{~g} / \mathrm{hd} / \mathrm{d}$ & Beef cattle & nc & + & - & {$[22]$} \\
\hline MPP & $300 \mathrm{~g} / \mathrm{hd} / \mathrm{d}$ & Dairy cows & + & $\mathrm{nc}$ & - & [20] \\
\hline \multicolumn{7}{|l|}{ Combination } \\
\hline $\mathrm{CO}+\mathrm{MP}$ & $50+30 \mathrm{~g} / \mathrm{kg}$ & Buffalo & $\mathrm{nc}$ & + & - & [54] \\
\hline$M P+G P$ & $9+1 \%$ & Beef cattle & $\mathrm{nc}$ & + & - & [22] \\
\hline MP + GP pellet & $200 \mathrm{~g} / \mathrm{hd} / \mathrm{d}$ & Beef cattle & nc & + & - & [22] \\
\hline
\end{tabular}

Abbreviations: GP garlic powder, MP mangosteen peel powder, MPP mangosteen peel pellet, CO coconut oil, nc not changed.

+ increased, - - decreased. 
Table 8 Effects of mangosteen peel powder supplement on population of rumen microbes

\begin{tabular}{ccccccccc}
\hline Substrates & Level, $\mathbf{g} / \mathbf{h} / \mathbf{d}$ & $\begin{array}{c}\text { Protozoa } \\
(+/-)\end{array}$ & $\begin{array}{c}\text { Methanogens } \\
(+/-)\end{array}$ & $\begin{array}{c}\text { RF } \\
(+/-)\end{array}$ & $\begin{array}{c}\text { RA } \\
(+/-)\end{array}$ & $\begin{array}{c}\text { FS } \\
(+/-)\end{array}$ & Species & References \\
\hline MP & 100 & $-^{*}$ & nd & nd & nd & nd & Beef cattle & {$[52]$} \\
MP & 100 & - & - & $+^{*}$ & $+^{*}$ & $+^{*}$ & Native cattle & {$[51]$} \\
MP & 300 & $-*$ & nd & + & + & + & Dairy cows & {$[20]$} \\
\hline
\end{tabular}

Abbreviations: MP mangosteen peel powder, plus symbol, minus symbol increase or decrease from control group, nd not determined, RF ruminococcus flavefaciens, $R A$ ruminococcus albus, FS fibrobactor succinogenes ${ }^{*} P<0.05$, significantly different from control group.

+ increased, - - decr.

(g/kg DM intake) in methane for each $10 \mathrm{~g} / \mathrm{kg} \mathrm{DM}$ addition of supplemental fat. While this is encouraging, many factors need to be considered such as the type of oil, the form of the oil (whole crushed oilseeds vs. pure oils), handling issues (e.g. coconut oil has a melting point of $25^{\circ} \mathrm{C}$ ) and the cost of oils which has increased dramatically in recent years due to the increased demand for food and industrial use. Few reports cover the effect of oil supplementation on methane emissions from dairy cows, where its impact on milk fatty acid composition and overall milk fat content would need to be carefully studied. Recent strategies, based on processed linseed, turned out to be very promising in both respects. Most importantly, a comprehensive whole system analysis needs to be carried out to assess the overall impact on global GHG emissions [45].

Manh et al. [56] reported that supplementation with Eucalyptus leaf meal at $100 \mathrm{~g} / \mathrm{d}$ for ruminants could be an alternative feed enhancer: it reduces the production of rumen methane gas in cattle, while the digestibility of nutrients was unchanged. Conversely, Pilajun and Wanapat [54] reported that increasing the coconut oil and Mago-pel levels decreased proportion of methane production, and that a suitable level should not exceed $6 \%$ for coconut oil and 4\% DM for MPP supplementation. In the future, comprehensive research into the individual components of essential oils, the physiological status of animals, the nutrient composition of diets and their effects on the rumen microbial ecosystem and metabolism of essential oils will be required to obtain consistent beneficial effects. Moreover, previous work, based on using plant secondary compounds and oils in both in vitro and in vivo trials, concerning rumen microorganisms, methane production and their impact on the mitigation of methane in the rumen, shows great potential for improving rumen ecology in the study of ruminant productivity (Table 9).

\section{Conclusion}

We can conclude that local feed resources are of prime importance for ruminant feeding especially in the tropics and sub-tropical regions. These resources can be established, developed and utilized for feed on the farm as well as being processed commercially by industrial enterprises. They can be used as sources of energy and/or protein either as ingredients in concentrate mixtures or as feed supplements. They have provided good results for enriching the efficiency of rumen fermentation and subsequent ruminant productivity as well as mitigating rumen methane. Using feeds containing plant secondary compounds and essential oils is recommended as a means for reducing rumen methane. However, the potential benefits of manipulating

Table 9 Effects of plant secondary compounds and plant oil on digestibility and methane gas production in various studies

\begin{tabular}{|c|c|c|c|c|}
\hline Substrates & Level & Methane,\% & Animal & References \\
\hline Garlic powder & $16 \mathrm{mg}$ & $(-) 22.0^{*}$ & Buffalo (fluid) & [55] \\
\hline Coconut oil & $16 \mathrm{mg}$ & (+) $6.4^{*}$ & Buffalo (fluid) & [55] \\
\hline Soapberry fruit and mangosteen peel pellet & $4 \%$ & 10.0 & Holstein heifers & [25] \\
\hline Mangosteen peel powder & $100 \mathrm{~g} / \mathrm{hd} / \mathrm{d}$ & $(-) 10.5$ & Beef cattle & [51] \\
\hline Coconut oil & $7 \%$ & (+) $39.5^{*}$ & Beef cattle & [51] \\
\hline Coconut oil & $7 \%$ & $(-) 10.2^{*}$ & Buffalo & [55] \\
\hline Coconut oil Garlic powder & $8: 4(\mathrm{mg})$ & $(-) 18.9^{*}$ & Buffalo & [55] \\
\hline Coconut oil + Garlic powder & $7 \%+100 \mathrm{~g}$ & $(-) 9.1^{*}$ & Buffalo & [55] \\
\hline Eucalyptus oil & $0.33-2 \mathrm{ml} / \mathrm{L}$ & $30.3-78.6 \%$ & Sheep & [57] \\
\hline Eucalyptus oil & $0.33-1.66 \mathrm{ml} / \mathrm{L}$ & $4.47-61.0 \%$ & Buffalo & [58] \\
\hline Eucalyptus meal leaf & $100 \mathrm{~g} / \mathrm{d}$ & reduce & Cow & [56] \\
\hline
\end{tabular}

* Values are significantly different $(P<0.05)$ from control group;,+- the values were increased or decreased from control group. 
rumen ecology to improve feed utilization efficiency in ruminants warrants undertaking further research and development in this area.

\section{Competing interests}

The authors declare that they have no competing interests.

\section{Authors' contributions}

MW conceived of the manuscript's purpose and design and critically revised the manuscript. SK and SP wrote and revised the manuscript according to MW's suggestions. All authors read and approved the final manuscript submitted.

\section{Author details}

${ }^{1}$ Tropical Feed Resources Research and Development Center (TROFREC), Department of Animal Science, Faculty of Agriculture, Khon Kaen University, Khon Kaen 40002, Thailand. ${ }^{2}$ Department of Animal Science, Faculty of Natural Resources, Rajamangala University of Technology-Isan, Sakon Nakhon Campus, Phang Khon, Sakon Nakhon 47160, Thailand.

Received: 9 June 2013 Accepted: 21 August 2013

Published: 27 August 2013

\section{References}

1. Wanapat M, Chanthakhoun V, Kongmun P: Practical Use of local feed resources in improving rumen fermentation and ruminant productivity in the tropics, In proceedings of 14th animal science congress of the AsianAustralasian association of animal production societies (14th AAAP). Pingtung, Taiwan, Republic of China: AAAP; 2010:635-645. 1.

2. FAO: Food and agriculture organization. Rome Italy: STAT database; 2008. Available online: www.fao.org.

3. FAO: Food outlook: global market analysis. Rome, Italy: Trade and Markets Division, FAO; 2009:42-51.

4. Delgado CL, Rosegrant M, Steinfeld H, Ehui S, Courbois C: Livestock to 2020 the next food revolution. Food agriculture, and environment discussion paper 28. Washington D.C: International Food Policy Research Institute; 1999.

5. Wanapat M: Potential used of local feed resources for ruminants. Trop Anim Health Prod 2009, 41:1035-1049.

6. Devendra C, Leng RA: Feed resources for animals in Asia: issues, strategies for use, intensification and integration for increased productivity. Asian-Aust J Anim Sci 2011, 24(3):303-321.

7. USEPA: Global mitigation of Non-CO2 greenhouse gases. Washington, DC: U.S. Environmental Protection Agency, Office of Atmospheric Programs (6207J); 2006.

8. IPCC: Summary for Policymakers. In Climate change 2007: mitigation. Contribution of working group III to the fourth assessment report of the intergovernmental panel on climate change. Edited by Metz B, Davidson OR, Bosch PR, Dave R, Meyer LA. Cambridge, United Kingdom and New York, NY, USA: Cambridge University Press; 2007.

9. Goodland R, Anhang J: Livestock and climate change: what if the key actors in climate change are... cows, pigs and chickens. World Watch 2009, 22(6):10-19.

10. Steinfeld H, Gerber P, Wassenaar T, Castel V, Rosales M, De Haan C Livestock's Long shadow: environmental issues and options. Rome, Italy: Food and Agriculture Organization (FAO); 2006:390

11. Wang Y, McAllister TA, Yanke $L$, Cheek PR: Effect of steroidal saponin from Yucca schidigera extract on ruminant microbes. J Appl Microbiol 2000, 88:887-896

12. Calabrò S, Guglielmelli A, lannaccone F, Danieli PP, Tudisco R, Ruggiero C, Piccolo G, Cutrignell MI, Infascelli F: Fermentation kinetics of sainfoin hay with and without PEG. J Anim Physiol Anim Nutr 2012, 96(5):842-849.

13. Makkar HPS, Sen S, Blummel M, Becker K: Effect of fractions containing saponins on rumen fermentation. J Agri Food Chem 1998, 46:4324-4328.

14. Cotlle DJ, Nolan JV, Wiedemann SG: Ruminant enteric methane mitigation: a review. Anim Prod Sci 2011, 51:491-514.

15. Wanapat $\mathrm{M}$, Chanthanhkoun V, Pilajun R: Dietary manipulation to reduce rumen methane production. Chiang Mai University J of Natur Sci 2012, 11:483-490.

16. Guglielmelli A, Calabrò S, Cutrignelli M, Gonzalez O, Infascelli F, Tudisco R, Piccolo V: In vitro fermentation and methane production of fava and soy beans. EAAP Scientific Series 2010, 127(1):457-460.
17. Hale WH, Theurer CB: Feed preparation and processing. In Digestive physiology and nutrition of ruminants, Volume 3. Edited by Church DC. Corvallis, OR, USA: Dept. Animal Science, Oregon State University; 1972:49-76.

18. Huyen NT, Wanapat M, Navanukraw C: Effect of mulberry leaf pellet (MUP) supplementation on rumen fermentation and nutrient digestibility in beef cattle fed on rice straw-based diets. Anim Feed Sci Technol 2012, 175:8-15.

19. Tan ND, Wanapat M, Uriyapongson S, Cherdthong A, Pilajun R: Enhancing mulberry leaf meal with urea by pelleting to improve rumen fermentation in cattle. Asian-Aust J Anim Sci 2012, 25:452-461.

20. Norrapoke T, Wanapat M, Wanapat S: Effects of protein level and mangosteen peel pellets (mago-pel) in concentrate diets on rumen fermentation and milk production in lactating dairy crossbreds. Asian-Aust J Anim Sci 2012, 25(7):971-979.

21. Manasri N, Wanapat M, Navanukraw C: Improving rumen fermentation and feed digestibility in cattle by mangosteen peel and garlic pellet supplementation. Livest Sci 2012, 148:291-295.

22. Trinh THN, Wanapat M, Thao TN: Effect of mangosteen peel, garlic and urea pellet supplementation on rumen fermentation and microbial protein synthesis of beef cattle. Agric J 2012, 7(2):95-100.

23. Hung LV, Wanapat M, Cherdthong A: Effects of leucaena leaf pellet on bacterial diversity and microbial protein synthesis in swamp buffalo fed on rice straw. Livest Sci 2013, 151:188-197.

24. Phesatcha K, Wanapat M: Performance of lactating dairy cows fed a diet based on treated rice straw and supplemented with pelleted sweet potato vines. Trop Anim Health Prod 2013, 45(2):533-538.

25. Poungchompu O, Wanapat M, Wachirapakorn C, Wanapat S, Cherdthong A: Manipulation of ruminal fermentation and methane production by dietary saponins and tannins from mangosteen peel and soapberry fruit. Arch Anim Nutr 2009, 63:389-400.

26. Polyorach $P$, Wanapat $M$, Wanapat $S$ : Increasing protein content of cassava (Manihot esculenta, Crantz) using yeast in fermentation. Khon Kaen Agr J 2012, 40(suppl 2):178-182.

27. Wanapat M, Polyorach S, Chanthakhoun V, Sornsongnern N: Yeastfermented cassava chip protein (YEFECAP) concentrate for lactating dairy cows fed on urea-lime treated rice straw. Livest Sci 2011, 139:258-263.

28. Nelson GEN, Anderson RF, Rhodes RA, Shekleton MC, Hall HH: Lysine, methionine and tryptophane content of microorganisms II. Yeast Appl Microbiol 1959, 8:179-182.

29. Polyorach S, Wanapat M, Wanapat S: Enrichment of protein content in cassava (Manihot esculenta Crantz) by supplementing with yeast for use as animal feed. Emir J Food Agric 2013, 25(2):142-149.

30. Robinson PH: Effect of yeast culture (Saccharomyces cerevisiae) on adaptation of cows to diets postpartum. J Dairy Sci 1997, 80:1119-1125.

31. Lila ZA, Mohammed N, Yasui T, Kurokawa Y, Kanda S, Itabashi H: Effects of a twin strain of Saccharomyces cerevisiae live cells on mixed ruminal microorganism fermentation in vitro. J Anim Sci 2004, 82:1847-1854

32. Robinson PH, Garrett JE: Effect of yeast culture (Saccharomyces cerevisiae) on adaption of cows to postpartum diets and on lactational performance. J Anim Sci 1999, 77:988-999.

33. Hristove AN, Varga G, Cassidy T, Long M, Heyler K, Karnati SKR, Corl B, Hovde CJ, Yoon I: Effect of Saccharomyces cerevisiae fermentation product on ruminal fermentation and nutrient utilization in dairy cows. J Dairy Sci 2010, 93(2):682-692.

34. Strohlein $\mathrm{H}$ : Back to nature, live yeasts in feed for dairy cows, DMZ. Lebensm Ind Milchwirtsch 2003, 124:68-71.

35. Desnoyers M, Giger-Reverdin S, Bertin G, Duvaux-Ponter C, Sauvant D: Metha-analysis of the influence of Saccharomyces cerevisiae supplementation on ruminal paramitters and milk production of ruminants. J Dairy Sci 2009, 92:1620-1632.

36. Boonnop K, Wanapat M, Nontaso N, Wanapat S: Enriching nutritive value of cassava root by yeast fermentation. Sci Agric (Piracicaba, Braz.) 2009, 66:616-620.

37. Boonnop K, Wanapat M, Navanukraw C: Replacement of soybean meal by yeast fermented-cassava chip protein (YEFECAP) in concentrate diets fed on rumen fermentation, microbial population and nutrient digestibilities in ruminants. J Anim Vet Adv 2010, 9:1727-1734. 
38. Wanapat M, Boonnop K, Promkot C, Cherdthong A: Effects of alternative protein sources on rumen microbes and productivity of dairy cows. Mj Int J. Sci Tech 2011, 5(1):13-23.

39. Khampa S, Chuelong S, Kosonkittiumporn S, Khejornsart P: Manipulation of yeast fermented cassava chip supplementation in dairy heifer raised under tropical condition. Pak J Nutr 2010, 9:950-954

40. Khampa S, Chawarat $P$, Singhalert $R$, Wanapat M: Supplement of yeast fermented cassava chip (YFCC) as a replacement concentrate and ruzi grass on rumen ecology in native cattle. Pak J Nutr 2009, 8(5):597-600,

41. Polyorach S, Wanapat M, Sornsongnern N: Effect of yeast fermented cassava chip protein (YEFECAP) in concentrate of lactating dairy cows. In proceedings of the 14th animal science congress of the Asian-Australasian association of animal production societies (AAAP), vol. 3, August 23-26, 2010. Pingtung, Taiwan, Republic of China: National Pingtung University of Science and Technology; 2010:304-307.

42. Beauchemin KA, Kreuzer M, O'Mara F, McAllister TA: Nutritional management for enteric methane abatement: a review. Aust J Exp Agric 2008, 48:21-27.

43. Guglielmelli A, Calabro S, Primi R, Carone F, Cutrignelli MI, Tudisco R, Piccolo G, Ronchi B, Danieli PP: In vitro fermentation patterns and methane production of sainfoin (Onobrychis ViciifoliaScop.) hay with different condensed tannin contents. Grass Forage Sci 2011, 66:488-500.

44. Chanthakhoun V, Wanapat M, Wachirapakorn C, Wanapat S: Effect of legume (Phaseolus calcaratus) hay supplementation on rumen microorganisms, fermentation and nutrient digestibility in swamp buffalo. Livest Sci 2011, 140:17-23.

45. Rowlinson P, Steele M, Nefzaoui A: Livestock and global climate change, In proceedings of the international conference in Hammamet, 17-20 May 2008. Cambridge: Cambridge University Press; 2008:216.

46. Grainger C, Clarke T, Auldist MJ, Beauchemin KA, McGinn SM, Waghorn GC, Eckard RJ: Mitigation of greenhouse gas emissions from dairy cows fed pasture and grain through supplementation with Acacia mearnsii tannins. Can J Anim Sci 2009, 89:241-251.

47. Woodward SL, Waghorn GC, Laboyrie P: Condensed tannins in birdsfoot trefoil (Lotus corniculatus) reduced methane emissions from dairy cows. Proc NZ Soc Anim Prod 2004, 64:160-164.

48. McAllister TA, Newbold CJ: Redirecting rumen fermentation to reduce methanogenesis. Aust J Exper Agri 2008, 48:7-13.

49. Sirochi SK, Pandey N, Goel N, Singh B, Mohini M, Pandey P, Chaudhry PP: Microbial activity and ruminal methane as affected by plant secondary metabolites in different plant extracts. Int J Environ Sci Engineering 2009, 1:52-58.

50. Beauchemin KA, McGinn SM: Methane emission from beef cattle: effects of fumaric acid, essential oil and canola oil. J Anim Sci 2006, 84:1489-1496.

51. Kongmun P, Wanapat M, Nontaso N, Nishida T, Angthong W: Effect of phytochemical and coconut oil supplementation on rumen ecology and methane production in ruminants, In proceedings of FAO/IAEA international symposium on sustainable improvement of animal production and health: 8-11 June 2009. Vienna, Austria: FAO/IAEA; 2009:246-247.

52. Ngamsaeng A, Wanapat M, Khampa S: Effects of mangosteen peel (Garcinia mangostana) supplementation on rumen ecology, microbial protein synthesis, digestibility and voluntary feed intake in cattle. Pakist J Nutr 2006, 5:445-452.

53. Kanpukdee S, Wanapat M: Effects of mangosteen (Garcinia mangostana) peel and sunflower and coconut oil supplementation on rumen fermentation, milk yield and milk composition in lactating dairy cows. Livest Res Rural Dev 2008, 20(Suppl). http://www.lrrd.org//rrd20/supplement/ such2.htm.

54. Pilajun $\mathrm{P}$, Wanapat M: Effect of coconut oil and mangosteen peel supplementation on ruminal fermentation, microbial population, and microbial protein synthesis in swamp buffaloes. Livest Sci 2011, 141:148-154.

55. Kongmun $P$, Wanapat $M$, Pakdee $P$, Navanukraw C: Effect of coconut oil and garlic powder on in vitro fermentation using gas production technique. Livest Sci 2010, 127:38-44.

56. Manh NS, Wanapat M, Uriyapongson S, Khejornsart P, Chanthakhoun V: Effect of eucalyptus (Camaldulensis) leaf meal powder on rumen fermentation characteristics in cattle fed on rice straw. African J Agri Res 2012, 7(13):1997-2003.
57. Sallam SMA, Bueno ICS, Brigide P, Godoy PB, Vitti DMSS, Abdalla AL: Efficacy of eucalyptus oil on in vitro rumen fermentation and methane production. Options Mediterraneennes 2009, 85:267-272.

58. Kumar R, Kamra DN, Agrawal N, Chaudhary LC: Effect of eucalyptus (Eucalyptus globules) oil on in vitro methanogenesis and fermentation of feed with buffalo rumen liquor. Anim Nutr Feed Technol 2009, 9:237-243.

doi:10.1186/2049-1891-4-32

Cite this article as: Wanapat et al: Development of feeding systems and strategies of supplementation to enhance rumen fermentation and ruminant production in the tropics. Journal of Animal Science and Biotechnology 2013 4:32.

\section{Submit your next manuscript to BioMed Central and take full advantage of:}

- Convenient online submission

- Thorough peer review

- No space constraints or color figure charges

- Immediate publication on acceptance

- Inclusion in PubMed, CAS, Scopus and Google Scholar

- Research which is freely available for redistribution 